\title{
Is the Crime of Aggression Really Accountable? Reflections about Syria
}

\author{
Ilich Felipe Corredor Carvajal
}

\author{
University "Del Rosario", Bogotá, Colombia; Univeristy Aix Marseille, Aix en Provence, France
}

\begin{abstract}
Nobody can deny that Syria's situation is really serious, and requires an effective solution from the international community. However, that "intervention/solution" will have to respect the UN Charter and the Security Council's responsibilities like the non intervention principle and the new definition of the crime of aggression adopted in Kampala in 2010. This paper analyses the role of major powers (especially the USA and France) and the hypothetic application of the article 8 bis of the Rome Statute, if the Security Council is not able to find a consensus, and a "unilateral" solution was carried out by the aforementioned powerful States.
\end{abstract}

Keywords: ICC, aggression, Security Council, non intervention principle, unilateral intervention.

Since the first months of 2012 the global media have informed about Syria's situation, and each day the world has witnessed barbarism, cruelty and violence, mainly with the repression directed by the head of government, Bashar Al-Asad. Some kind of accord can be find around the idea that the "Arab spring" had influence on the beginning of Syrian conflict. It is of note that the only regime that managed to stay in power was the Syrian government which resorted to disproportionate and unlimited use of armed force. The information cannot be exact, but the chemical weapons attack took place after more than 100,000 deaths in Syria according to The Washington Post (August 31, 2013).

In principle, like every conflict of this type, it is possible to recognize at least two parties with opposing interests: a government who claims and defends its legitimate "right" to continue to rule, and the "rebels" who fight to achieve a change in the current regime. However, Syira's situation cannot be ignored because of disproportionate, bloody and illegitimate government's repression against rebels and civilians. No exercise of power may be justified on international law and legality, in the violent, sanguinary and widespread attacks directed against its own civilian population.

International activity has been considerable. On 1 March 2012, the Security Council claimed to "deplore the rapidly deteriorating humanitarian situation, in particular the growing number of affected civilians, the lack of safe access to adequate medical services, and food shortages, particularly in areas affected by fighting

*Address correspondence to this author at the University "Del Rosario", Bogotá, Colombia; Univeristy Aix Marseille, Aix en Provence, France; Tel: (57)3102228383; E-mail: corredor.ifelipe@gmail.com and violence such as Homs, Hama, Deraa and Idlib" (UN, press, 2012); on May 27 2013, the Security Council "demanded that the Government of Syria immediately cease the use of heavy weapons in population centres and immediately pull back its troops and its heavy weapons from in and around population centres and return them to their barracks" (UN, press, 2012); and on June 7 2013, The Security Council stated that they "express their grave concern about the humanitarian impact of the recent heavy fighting in AlQusayr" (UN, press, 2013).

Two resolutions have been adopted by The Security Council: first, resolution 2042 (2012) called upon i) "the Syrian government to implement visibly its commitments in their entirety, as it agreed to do in its communication of the Envoy of 1 April 2012, to (a) cease troop movements towards population centres, (b) cease all use of heavy weapons in such centres, and (c) begin pullback of military concentrations in and around population centres"; and ii) "all parties in Syria, including the opposition, immediately to cease all armed violence in all its forms"; second, resolution 2043 (2012) "decides to establish for an initial period of 90 days a United Nations Supervision Mission in Syria (UNSMIS) under command of a chief Military observer". The resolution 2059 extended UNSMIS for a final period of 30 days, but violence neither stopped nor decreased.

Then General Robert Mood (2012) had to recognize "there has been an intensification of armed violence across Syria over the past 10 days. This escalation is limiting our ability to observe, verify, report as well as assist in local dialogue and stability projects - basically impeding our ability to carry out our mandate. The lack of willingness by the Parties to seek a peaceful transition, and the push towards advancing military 
positions is increasing the losses on both sides: innocent civilians, men, women and children are being killed every day. It is also posing significant risks to our observers. In this high risk situation, UNSMIS is suspending its activities"

Despite the efforts of the UN and the international community, finishing 2013 the situation is almost the same or even more serious. The world sees, even today, how this conflict has worsened to the point of using chemical weapons by The Assad government. For these reasons and after the French government report (Programmechimiquesyrien Casd 'emploipassésd' agentschimiques par le régime Attaquechimiqueconduite par le régime, 21 August 2013) about the chemical attack carried out 21 August 2013, "France and the US are pushing for punitive military action" but "the UK parliament rejected" (BBC, 2013). Even human rights organizations concluded that "available evidence strongly suggests that Syrian government forces were responsible for chemical weapons attacks on two Damascus suburbs on August 21, 2013" (HRW, 2013). But there are many people who affirm that the first chemical attack was, at least, on 11 April (Le Monde, 2013). The situation is so serious that, Ban Ki-moon, "in unusual candor (...) said that Syrian President Bashar Assad "has committed many crimes against humanity"' (CBS, 2013)

Nobody can deny that Syria's situation is really serious and requires some kind of effective solution from the international community. But as had been announced "interventions/solutions" have to respect the UN Charter (Article 2.7), the Security Council's responsibilities (chapters $\mathrm{V}$ and VII, Article 24.1), the non intervention principle (Resolution GA 2625 - XXV) and the new definition of the crime of aggression adopted in Kampala in 2010 (Resolution RC/Res.6.), the last topic which had a main role in this analysis.

Outside of the UN charter - chapter VII and without the Security Council's authorization, any intervention in Syria could, in a hypothetical way because the amendments on the crime of aggression have not entered into force yet, could constitute a crime of aggression; but could an intervention with humanitarian purposes constitute a crime of aggression under the Rome Statute. For example, Russian government has already affirmed that "the use of force without a U.N. mandate would violate international law" and "the use of force without the approval of the United Nations Security Council is a very grave violation of international law"(REUTERS, 2013). The Russian government opposition, as a permanent member of the Security Council, prevents a resolution from being adopted under the chapter VII, in this manner the real politik, once again, prevails over a legal and urgent action.

Everybody knows of the numerous cases in which a powerful State has the initiative to intervene in domestic situations, even if these decisions have to be, according to UN Charter (Article 1.2), "based on respect for the principle of equal rights and selfdetermination of peoples". For example the USA has unilaterally intervened on Iraq and Afghanistan, even without the authorization of the Security Council, because it is the most powerful State, but not because the USA respects international law. However, the focus in this paper is the definition of crime of aggression and its real application, without analyzing unilateralism in international law, because once article 8 bis of Rome Statute is adopted, uniteralism won't be relevant to punish leaderships.

Thus, since a legal perspective which cannot forget that according to the Rome Statue Preamble "during this century millions of children, women and men have been victims of unimaginable atrocities that deeply shock the conscience of humanity" and "that the most serious crimes of concern to the international community as a whole must not go unpunished and that their effective prosecution must be ensured' and with the existence of arguments to suggest that it could be possible to prosecute perpetrators of crime of aggression in international law even without a legal definition (CASSESE, 2007), agreement achieved in 2010 (Resolution RC/Res.6.), i) should US and French governments intervene despite the opposition and the lack of authorization, and ii) would the "new" definition of the crime of aggression would apply in a case like this. Even if the two answers are negative, from my view, the punishment of aggression requires a more specific analysis because in every single case the political reasons prevail over the necessity of accountability, and this is no exception.

The world needed two World wars, millions of deaths, thousands of internal conflicts, five decades of political polarization between west and east and other fateful events to take a smart decision adopting the Definition of the crime of aggression in article 8 bis in 2010 at the Rome Statue Review Conference, held in Kampala. However, it is good to say it, the adopted definition is really very close to resolution 3314 UN General Assembly and this link has a negative effect 
over the "new" definition (HongjuKoh, 2010), because the definition can be characterized as outdated and disconnected from the modern challenges of relations between states and forms of use of armed force (CORREDOR, 2012).

The beginning is the article 8 bis which defines, for the purpose of the Rome Statute, the crime of aggression as "the planning, preparation, initiation or execution, by a person in a position effectively to exercise control over or to direct the political or military action of a State, of an act of aggression which, by its character, gravity and scale, constitutes a manifest violation of the Charter of the United Nations".

In this sense, we have to analyze three categories: i) what is the action punished, ii) who had the political and military control over the action and iii) what kind of act of aggression was committed, to know who will be responsible for having committed a crime of aggression under Rome Statute, if any State takes the decision to attack Syria. Above all, it's necessary to remember that act without authorization or intervention of the Security Council, the body charged with the primary responsibility for the maintenance of international peace and security, could be understood as a manifest violation of the Charter.

Since Kampala 2010, we know that planning, preparation, initiation or execution are going to be the punished acts. In other words, the judicial punishment is going to be for the successive and coordinated development of the three phases of the crime with a progressive and orderly relationship between stages like planning for the act, preparing to obey the predetermined plan and execution, performance or lauch of the act of aggression, when we can distinguish between what has been planned and what has been prepared.

As the same definition reads, the crime of aggression is, without question, a crime of leaderships. The definitions requires "a person in a position effectively to exercise control over or to direct the political or military action of a State", this element has to be understood as the fact that he or she exercised a leadership role, and the evidence considered as to whether the defendant had a real chance to influence, determine and direct the criminal action, regardless of their position in government.

Then positions like President, First Minister, foreign affairs ministers and heads of armed forces of US and French governments could be targeted of this element of the definition. However, the definition does not have clear limits and it will be hard to establish the last person called to respond, but none American or French judge, even the ICC, will prosecute the US or French Presidents for two basic reasons: first, the intervention has a political support and humanitarian motivation and second, there is not jurisdiction over crime of aggression, as seen as follows, or it has not been adopted in each legislation.

In every case the leadership who commits an act of aggression will be responsible of aggression and for the Rome Statuteit "means the use of armed force by a State against the sovereignty, territorial integrity or political independence of another State, or in any other manner inconsistent with the Charter of the United Nations. Any of the following acts, regardless of a declaration of war, shall, in accordance with United Nations General Assembly resolution 3314 (XXIX) of 14 December 1974, qualify as an act of aggression: (...)"

US and French governments had announced the possibility to attack according to the BBC (30 August 2013), before resolution SC 2118 - 2013, adopted 27 September 2013 which "condemns in the strongest terms any use of chemical weapons in the Syriwn Arab Republic, in particular the attack on 21 august 2013, in violation of international law", "decides that the Syrian Arab Republic shall not use, develop, produce, otherwise acquire, stockpile or retain chemical weapons, or transfer, directly or indirectly, chemical weapons to other States or non-State actors" and "expresses its strong conviction that those individuals responsible for the use of chemical weapons in the Syrian Arab republic should be held accountable", but the decision never authorized an intervention or armed attack under chapter VII and the States have not renounceda armed intervention.

In other words and for the purpose of the Rome Statute if the USA or French government, or both, attack Syria by the armed forces, invade its territory, perform any military occupation, bombard the territory, use any weapons against the territory, blockade the Syrian ports or coasts, attack with their armed forces on the land, sea or air forces, or marine and air fleets of Syria, or send on their behalf armed bands, groups, irregulars or mercenaries, which carry out acts of armed force against Syria, it could be understood as an act of aggression under resolution 3314 and Rome Statute article 8 bis with consequences in personal responsibility for a State's act. 
If some of these possibilities came true, from a legal and objective view, there will be substantial grounds to believe that the person committed the crime of aggression. However, immediately at least three reason dismiss any procedure.

First, in Kampala it was decided that the Court's jurisdiction cannot be exercise before 1 January 2017 anyway, even if a manifest crime of aggression take place between the review conference and 31 December 2016. Moreover, for the real exercise of the ICC jurisdiction the amendment has to be ratified or accepted by thirty States Parties and only the jurisdiction will be activated with respect to crimes of aggression committed one year after the ratification or acceptance of the amendment by the State number thirty. Furthermore, the Court shall exercise jurisdiction over the crime of aggression subject to a decision to be taken after 1 January 2017 that is to say that even if is 2 January 2017 or thirty States Parties had ratified the amendment, the definition cannot be apply, unless each State Party can declared that it does not accept exercise jurisdiction over a crime of aggression (STAHN, 2010).

Second, USA and French governments are permanent members of the Security Council of UN, they are two of the famous "big five" and they can use their powers to defer the investigation.(Rome Statute article 16). Third, the USA is not a State Party of the Rome Statute and has not signed the crime of aggression amendment; France is a State party but it has not signed the crime of aggression amendment either; and nor is Syria a State Party. On September 2013, 11 States Parties have ratified the amendment on the crime of aggression: Liechtenstein (8 May 2012), Samoa (25 September 2012), Trinidad and Tobago (13 November 2012), Luxembourg (15 January 2013), Estonia (27 March 2013), Germany (3 June 2013), Botswana (4 June 2013), Cyprus (25 September 2013), Slovenia (25 September 2013), Andorra (26 September 2013) and Uruguay (26 September 2013).

USA and French governments had strongly defended their right and their duty to intervene with support in the most elemental considerations of humanity, but also emphasizing security reasons. President Obama (2013) remembered "(...) the facts cannot be denied. The question now is what the United States of America, and the international community, is prepared to do about it. Because what happened to those people -- to those children -- is not only a violation of international law, it's also a danger to our security. Let me explain why. If we fail to act, the Assad regime will see no reason to stop using chemical weapons (...) And a failure to stand against the use of chemical weapons would weaken prohibitions against other weapons of mass destruction, and embolden Assad's ally, Iran -- which must decide whether to ignore international law by building a nuclear weapon, or to take a more peaceful path. This is not a world we should accept. This is what's at stake. And that is why, after careful deliberation, I determined that it is in the national security interests of the United States to respond to the Assad regime's use of chemical weapons through a targeted military strike. The purpose of this strike would be to deter Assad from using chemical weapons, to degrade his regime's ability to use them, and to make clear to the world that we will not tolerate their use. That's my judgment as Commander-in-Chief. But I'm also the President of the world's oldest constitutional democracy"

After Russian political intervention and the adoption of resolution SC $2118 / 2013$ it is quite unlikely that the Syrian government will be the target of an armed attack, in despite of the number of deaths and gravity of crimes today committed. From a crime of aggression point of view it is a good solution because there will be no discussion around any crime or jurisdiction.

The world will never forget that "aggression, therefore, is not only an international crime; it is the supreme international crime differing only from other war crimes in that it contains within itself the accumulated evil of the whole" (IMTN, 1946). However, even today with a new definition of crime of aggression the punishment is not easy, because the article 8 bis RS has enormous substantial and jurisdiction problems before being applied and this was the decision held in Kampala: to adopt a new definition without intention to really activate the Court's Jurisdiction (AMBOS, 2010). If a State attacks or incursin any act of the paragraph 2 of the article 8 bis (KREB and VON HOLTZENDORFF, 2010) of the Rome Statute, without Security Council intervention or authorization under chapter VII, from a legal and objective view there will be substantial grounds to believe that a crime of aggression was committed, even if political or humanitarian considerations are claimed or the procedure cannot be triggered.

\section{REFERENCES}

AMBOS Kai "The crime of aggression after Kampala", German YearBook of International Law, Vol 53, 2010 
BLOKKER (N)/ KRESS (C) "A consensus agreement on the crime of aggression: impressions from Kampala", LJIL, 2010, 23(4), p.889-895

CASSESE Antonio "On Some Problematical Aspects of the Crime of Aggression", LJIL, 20, 2007,p 841-849

CLARK $(R)$, "Negotiating Provisions Defining the Crime of Aggression, its Elements and the Conditions for ICC Exercise of Jurisdiction Over it», EJIL, Vol. 20, n 4, 2009, p. 1103 1115

CORREDOR Felipe "El crimen de agresión en derecho penal internacional. Responsabilidad del individuo por acto de estado", Editorial Universidad de Rosario (Colombia), 2012.

FERENCZ (D) "Bringing the crime of aggression within the active jurisdiction of the ICC", Case Western Reserve Journal of International Law, 2009, 42, p. 531-542.

FERENCZ (D. M.) "The crime of aggression: some personal reflections on Kampala", LJIL, 2010, 23(4), 905-908

HEAPHY (M), "The United States and its interests in the 2010 review conference of the Rome statute of the ICC", RIDP, Vol. 81, 2010, p. 77- 97.

HONGJU KOH Harold Statement, Legal Adviser. U.S. Department of State. Review Conference of the International Criminal Court", 4 June 2010.

KAMTO (M) L'agression en droit international, Pedone, Paris, 2010, $464 \mathrm{p}$.

KOLB (R) Droit international pénal, HelbingLichtenhahn, 2008, 488 p.

KREB (C)/VON HOLTZENDORFF (L) "The Kampala Compromise on the Crime of Aggression, Journal of International Criminal Justice, Vol. 8, 2010

MOODRobert (General) Statement of the Head of the UN Supervision Mission in Syria, 16 June 2012

MURPHY (S-D) "Aggression, Legitimacy and the International Criminal Court", EJIL, Vol. 20, n 4, 2009, 1147-1156

PAULUS (A) "Second Thoughts on the Crime of Aggression", EJIL, Vol. $20, n^{\circ} 4,2009$, p. 1117-1128.
STAHN Carsten "The "end", the "beginning of the end" or the "end of the beginning"? Introducing debates and voices on the definition of "aggression", LJIL, 2010, 23(4),

UN Charter

Resolution GA 2625 (XXV)

Resolution RC/Res.6.

Resolution 3314 (XXIX)

Resolution SC 2042 (2012)

ResolutionSC 2043 (2012)

Rome Statue

The BBC Syrian government 'behind chemical attack'

2 September 2013

CBS United Nations' Syria chemical weapons report "overwhelming," Secretary-General Ban Ki-moon says

13 September 2013

HRW Syria: Government Likely Culprit in Chemical Attack,

10 September 2013

Attacks on Ghouta, Analysis of Alleged Use of Chemical Weapons in Syria

10 September 2013

Le Monde Guerrechimique en Syrie - Sur le front de Damas 27 May 2013

Reuters Russia warns against military intervention in Syria 26 August 2013

The Washington Post In Syria, chemical weapons attack evoked visceral response

August 31, 2013

http://www.un.org/News/Press/docs/2012/sc10564.doc.htm http://www.un.org/News/Press/docs//2012/sc10658.doc.htm http://www.un.org/News/Press/docs//2013/sc11028.doc.htm

Received on 25-11-2013

Accepted on 05-03-2014

Published on 20-03-2014

DOI: http://dx.doi.org/10.6000/1929-4409.2014.03.09

(C) 2014 Ilich Felipe Corredor Carvajal; Licensee Lifescience Global.

This is an open access article licensed under the terms of the Creative Commons Attribution Non-Commercial License (http://creativecommons.org/licenses/by-nc/3.0/) which permits unrestricted, non-commercial use, distribution and reproduction in any medium, provided the work is properly cited. 